\title{
PENERAPAN TEKNIK GUIDED NOTE TAKING DALAM MENINGKATKAN KEMAMPUAN MEMBACA TEKS DRAMA
}

\section{Andriani* $^{*}$}

\section{ABSTRACT}

The purpose of research study to describe about influence of the guided note taking technique to skill of reading drama text. Outcomes through the application of guided note taking technique of student class VIIIB SMP Negeri 2 Mamasa. The research is classroom action research. Procedur of the research is (1) planning, (2) action, (3) observation, and (4) reflection. The instruments used is a test of reading drama text and observation of student activity. In the first cycle the results showed that the average of skill of reading drama text is 70,08, and second cycle the average of skill of reading drama text is 75,00. Which means that the application of guided note taking can improve reading drama text skill of students.

Keywords: Guided Note Taking Technique, Skill of Reading Drama Text

\section{PENDAHULUAN}

Manusia dan pendidikan tidak dapat dipisahkan satu dengan yang lainnya. Pendidikan mempunyai peranan penting untuk menjamin perkembangan dan kelangsungan hidup suatu bangsa, karena pendidikan merupakan wahana untuk meningkatkan dan mengembangkan kualitas sumber daya manusia. Berdasarkan UndangUndang RI Nomor 20 tahun 2003 tentang sistem Pendidikan Nasional Bab I pasal 1 ayat 1 menyatakan bahwa pendidikan adalah usaha sadar dan terencana untuk mewujudkan suasana belajar dan proses pembelajaran agar peserta didik secara aktif mengembangkan potensi dirinya untuk memiliki kekuatan spiritual keagamaan, pengendalian diri,

*) Prodi Pendidikan Bahasa Indonesia, Universitas Al Asyariah Mandar E-mail: andriani@,unasman.ac.id 
kecerdasan, akhlak mulia, serta keterampilan yang diperlukan dirinya, masyarakat, bangsa, dan negara (Masdudi dan Nasehuddin, 2009:2).

Pernyataan tersebut menjelaskan bahwa tujuan pendidikan dapat tercapai dengan suasana belajar dan proses pembelajaran yang terencana dengan baik. Dalam memenuhi tuntutan perkembangan jaman yang semakin maju, aspek pendidikan diharuskan membimbing dan mengarahkan peserta didik untuk menjadi lebih aktif dan kreatif. Keaktifan Peserta didik hendaklah melibatkan Peserta didik Dalam memenuhi tuntutan perkembangan jaman yang semakin maju, aspek pendidikan diharuskan membimbing dan mengarahkan peserta didik untuk menjadi lebih aktif dan kreatif. Keaktifan Peserta didik hendaklah melibatkan Peserta didik itu sendiri agar secara langsung dapat belajar dan menemukan sebuah jawaban dalam setiap pertanyaan dan permasalahan yang diutarakan.

Dalam pengajaran bahasa disajikan secara bermakna sebagai suatu keutuhan, yaitu dalam konteks penggunaannya pada komunikasi, bukan sebagai butiryang terpotong-potong. Sebab, dalam berkomunikasi kalimat yang digunakan bukan kalimat yang terpotong-potong, melainkan kalimat yang saling berkaitan dan bermakna.

Tujuan pendidikan pada hakekatnya ingin merubah perilaku, intelektual dan moral maupun sosial agar bisa mandiri dalam kehidupan di masyarakat. Dalam mencapai tujuan pendidikan tersebut Peserta didik berinteraksi dengan lingkungan belajar yang diatur oleh guru melalui proses pembelajaran. 
Guru merupakan kunci dan sekaligus ujung tombak pencapaian misi pembaharuan pendidikan, mereka berada di titik sentral untuk mengatur, mengarahkan dan menciptakan suasana kegiatan belajar mengajar untuk mencapai tujuan dan misi pendidikan nasional yang dimaksud. Oleh karenanya secara tidak langsung guru dituntut untuk lebih profesional, inovatif, persepektif dan proaktif dalam melaksanakan tugas pembelajaran.

Dalam pembelajaran guru dituntut kreatif mengelola kelas dan memberikan suasana belajar yang menunjang peserta didik memperoleh pengalaman belajarnya. Berbagai komponen pembelajaran seperti tujuan, bahan, metode, media serta penilaian pembelajaran merupakan bahan garapan guru yang digunakan dalam interaksi antara guru dan peserta didik (Sudjana dan Rivai, 2002: 1).

Berdasarkan hasil observasi pendahuluan yang dilakukan oleh peneliti pada pembelajaran bahasa Indonesiadalam keterampilan membaca Kelas VIIIB SMP Negeri 2 Mamasa sebagian besar peserta didik masih kurang memberikan perhatian ketika proses pembelajaran berlangsung. Indikator tersebut dapat dilihat ketika peneliti melakukan observasi dan hasil wawancara dengan guru. Guru menyatakan bahwa nilai dari $60 \%$ peserta didik belum memenuhi KKM yaitu sebesar 75. Hal ini disebabkan selama pembelajaran berlangsung, Peserta didik cenderung tidak aktif dan kurang ada timbal balik dari peserta didik. Terlihat bahwa perhatian peserta didik terhadap pembelajaran peserta didik masih kurang. Peserta didik sibuk mengobrol dan bercanda dengan menggunakan handphone dan membaca 
buku dengan teman, bahkan beberapa peserta didik bermain selain buku mata pelajaran yang sedang diajarkan. Selama proses pembelajaran, tidak ada satu pun peserta didik yang aktif untuk bertanya ataupun menjawab pertanyaan dari guru. Sehingga guru harus menunjuk salah satu peserta didik untuk menjawabnya. Ketika diberikan tugas dalam kelompok, terdapat beberapa Peserta didik yang tidak ikut serta dalam diskusi kelompok mereka.

Teknik yang biasa digunakan guru adalah metode ceramah, di mana peserta didik mendengarkan materi yang disampaikan guru tanpa ada timbal balik. Aktivitas yang dilakukan peserta didik adalah mencatat materi yang disampaikan guru. Sehingga selama pembelajaran, peserta didikmerasa bosan dan mengantuk. Agar dapat meningkatkan keaktifan belajar peserta didik saat pembelajaran memilih bahan baku busana, diperlukan pemilihan dan penerapan teknik pembelajaran yang tepat, yang disesuaikan dengan tujuan dan karakteristik mata pelajaran serta kondisi peserta didik. Guru yang kreatif berusaha untuk memilih teknik yang serasi dan juga sedapat mungkin diselingi yang baru sehingga peserta didik merasakan adanya kesegaran ketika menerima pelajaran di dalam kelas, terhindar dari rasa bosan dan mengantuk, bahkan pelajaran akan dirasakan tidak sulit dan menjadi disenangi karena adanya harmonisasi di dalam pemakaian metode.

Untuk mengatasi masalah keaktifan belajar agar tidak berkelanjutan maka perlu diterapkan model pembelajaran yang tepat. Model pembelajaran aktif yaitu suatu pembelajaran yang mengajak 
peserta didikuntuk belajar secara aktif. Mereka secara aktif menggunakan otak mereka baik untuk menemukan ide pokok dari materi pelajaran, memecahkan persoalan atau mengaplikasikan apa yang baru mereka pelajari ke dalam suatu persoalan yang ada dalam kehuidupan nyata (Zaini, 2002: 26). Dengan teknik pembelajaran aktif peserta didik dapat belajar secara aktif dan berinteraksi di dalam kelas. Sedangkan untuk mengatasi metode guru yang kurang menarik, makadapatmenggunakan teknik guided note taking.

Suprijono (2011: 105) menyatakan bahwa metode guided note taking merupakan metode belajar berupa catatan terbimbing yang dikembangkan. agar metode ceramah yang dibawakan guru mendapat perhatian Peserta didik. Dengan menggunakanteknik guided note takingpeserta didikdapatmelakukan aktivitas membaca pada handout guided note taking yang telah disediakan oleh guru.

Metode handout guided note taking yang telah disediakan guru.Maka model pembelajaran aktif metode guided note taking dikemas dalam bentuk diskusi dalam kelompok yang masing-masing terdiri atas 6 orang. Peserta didik bekerjasama, handout guided note taking, kemudian dilantukan berinteraksi dalam mengisi dengan presentasi dari wakil setiap kelompok. Guru meminta Peserta didik untuk saling menanggapi presentasi kelompok lain. Guru juga memotivasi peserta didik agar aktif untuk bertanya dan mengemukakan pendapatnya. Sehingga peserta didik terhindar dari rasa bosan dan mengantuk. Di sisi lain suasana belajar akan lebih hidup, komunikasi dua arah antara guru dan peserta didik dapat terjalin dengan baik. Pada akhirnya keaktifan 
belajar peserta didik pun meningkat dan keberhasilan pembelajarannya pun meningkat.

Sejalan dengan perkembangan ilmu pengetahuan dan teknologi yang semakin pesat, terutama dalam teknologi percetakan maka semakin banyak informasi yang tersimpan di dalam buku. Pada semua jenjang pendidikan, kemampuan membaca menjadi skala prioritas yang harus dikuasai peserta didik. Dengan membaca peserta didik akan memperoleh berbagai informasi yang sebelumnya belum pernah didapatkan. Semakin banyak membaca semakin banyak pula informasi yang diperoleh. Oleh karena itu, membaca merupakan jendela dunia, siapa pun yang membuka jendela tersebut dapat melihat dan mengetahui segala sesuatu yang terjadi. Baik peristiwa yang terjadi pada masa lampau, sekarang, bahkan yang akan datang.

Dalam keterbatasan-keterbatasan yang dimiliki oleh peserta didik maka sebagai pendidik diharuskan membuat metode pembelajaran yang lebih muda dalam mengarahkan anak didik untuk dapat lebih mengerti dan memahami tentang pelajaran yang di ajarkan, pengajar perlu menerapkan teknik atau metode yang efektif dengan melakukan penyesuaian dengan tingkat keterampilan peserta didik.

\section{METODE PENELITIAN}

Penelitian yang digunakan dalam penelitian ini adalah Penelitian Tindakan Kelas (Classroom Action Research). Penelitian tindakan kelas ini merupakan salah satu upaya praktisi beserta kolaborator dalam bentuk berbagai kegiatan yang di lakukan untuk memperbaiki dan meningkatkan 
mutu pembelajaran dikelas. Adapun hasil akhir yang diharapkan adalah meningkatnya kemampuan membaca teks Drama pada peserta didik kelas VIIIB SMP Negeri 2 Mamasa.

Penelitian ini akan menciptakan kaloborasi atau partisipasi antara peneliti dan pendidik kelas sesuai dengan pendapat Arikunto (2008: 17), bahwa dalam penelitian kolaborasi pihak yang melakukan tindakan adalah pendidik kelas sedangkan yang melakukan pengamatan terhadap berlangsungnya proses tindakan adalah peneliti. Maka dalam penelitian ini hubungan kolaborasi ini ditampilkan dalam keseluruhan proses perencanaan, pelaksanaan penelitian tindakan sampai dengan penyusunan laporan hasil tindakan. Dengan demikian, sejak perencanaan penelitian tindakan peneliti senantiasa terlibat, selanjutnya peneliti memantau, mencatat, dan mengumpulkan data lalu menganalisis data serta berakhir dengan melaporkan hasil penelitiannya.

Subjek penelitian ini adalah Kelas VIIIB SMP Negeri 2 Mamasa yang berjumlah 26 orang. Perempuan 15 orang dan laki-laki 11 orang. Subjek dipilih dalam penelitian karena peneliti menilai perlu adanya sebuah inovasi dalam kegiatan pembelajaran di Sekolah tersebut, khususnya mengenai menerapan metode pembelajaran dalam upaya meningkatkan kemampuan membaca, dengan tujuan agar anak termotivasi dalam mengikuti pembelajaran yang diharapkan dapat memberi dampak positif berupa peningkatan kemampuan membaca.

Instrumen penelitian adalah alat atau fasilitas yang digunakan oleh penelitidalam mengumpulkan data agar pekerjaannya lebih mudah dan hasilnya lebih cermat, lengkap, dan sistematis sehingga lebih mudah 
diolah. Dengan demikian, dapat dikatakan penelitian di dalam menerapkan metode penelitian menggunakan instrumen atau alat agar data yang diperoleh lebih baik (Arikunto, 2008:101). Penelitian ini peneliti menggunakan instrumen pengumpulan data berupa tes dan pengamatan/observasi.

Teknik pengumpulan data yang digunakan peneliti untuk mengumpulkan data adalah menggunakan metode sebagai berikut:

\section{Instrumen Tes}

Instrumen yang berupa tes digunakan untuk mengukur tingkat kemampuan membaca teks drama peserta didik. Instrumen yang berupa tes berisi soal esai yang harus diisi oleh peserta didik setelah mereka membaca. Peserta didik menjawab beberapa pertanyaan mengenai bacaan tersebut. Langkah yang diambil oleh peneliti dalam pengambilan data dengan menggunakan tes antara lain, 1) menyiapkan bahan bacaan teks drama, 2) mengukur kemampuan membaca teks drama peserta didik setelah diberikan tindakan yaitu dengan menggunakan teknik guided note taking, 3) menilai dengan mengolah data dari hasil pembelajaran.

\section{Observasi/Pengamatan}

Pengamatan atau observasi adalah suatu teknik atau cara mengumpulkan data dengan jalan mengadakan pengamatan terhadap kegiatan yang sedang berlangsung (Nana Syaodiah, 2010: 220). Dalam penelitian ini metode observasi digunakan untuk mendapatkan data perubahan suasana belajar mengajar. Observasi yang dilakukan terstruktur dengan menggunakan lembar observasi atau pengamatan. 
Teknik analisis data yang digunakan peneliti dalam melakukan penelitian tindakan kelas adalah analisis data kualitatif dan kuantitatif. Data kualitatif diperolehdari hasil pengamatan kemampuan membaca permulaan melalui teknik guided note taking, dokumentasi yang berupa deskripsi perilaku, deskripsi proses pembelajaran, dan foto. Sedangkan data kuantitatif yang berupa persentase jumlah peserta didik yang memperoleh nilai tertentu, akan dianalisis secara deskriptif kuantitatif.

\section{HASIL PENELITIAN DAN PEMBAHASAN}

Kemampuan membaca teks drama peserta didik pada awal pertemuan, terlihat masih kurang. Berdasarkan wawancara dengan guru, pembelajaran membaca teks drama yang selama ini dilakukan di SMP Negeri 2 Mamasa belum menggunakan cara yang tepat. Biasanya peserta didik langsung diminta untuk membaca teks drama tanpa menggunakan teknik tertentu. Kekurangan dari pembelajaran tersebut baru terlihat ketika hasil pekerjaan peserta didik masih kurang dari yang diharapkan. Dinilai dari segi suasana pembelajaran di kelas, peserta didik kurang termotivasi karena pembelajarannya monoton dan kurang menyenangkan.

Berdasarkan hasil tersebut dapat diketahui bahwa kemampuan peserta didik kelas VIIIB SMP Negeri 2 Mamasa dalam membaca teks drama masih rendah, atau masih berada di bawah indikator keberhasilan produk yakni lebih atau sama dengan 75,00. Melihat kondisi tersebut, kegiatan praktik membaca teks drama di sekolah perlu dilakukan perbaikan demi tercapainya hasil pembelajaran yang diinginkan. Salah satu langkah yang dilakukan oleh guru yakni dengan pengembangan 
variasi pembelajaran dengan penggunaan teknik pembelajaran yang tepat untuk menunjang kelancaran proses kegiatan belajar mengajar. Teknik pembelajaran yang dipilih oleh guru yakni teknik guided note taking. Teknik ini dipilih karena teknik ini menitik beratkan pada pola yang digunakan peserta didik untuk menuliskan pokok-pokok cerita. Pengajar bertindak sebagai fasilitator untuk menceritakan kembali teks drama yang dibaca.

Pelaksanaan pembelajaran dengan teknik guided note taking diterapkan dalam dua siklus. Fokus dari kegiatan ini adalah meningkatkan keterampilan membaca teks drama menggunakan teknik guided note taking pada peserta didik kelas VIIIB SMP Negeri 2 Mamasa agar memperoleh hasil yang maksimal. Pengajar dituntut untuk menjelaskan tahapan-tahapan membaca teks drama. Tahapan-tahapan tersebut di antaranya adalah menjelaskan teks drama secara umum, menjelaskan unsur intrinsik teks drama, pengertian teknik guided note taking, cara membuat lembar gagasan, dan menceritakan kembali teks drama berdasarkan lembar gagasan.

Berdasarkan hasil kerja peserta didik dari pratindakan hingga siklus II, kemampuan membaca teks drama peserta didik mengalami peningkatan. Peningkatan dari pratindakan hingga siklus I adalah sebesar 70,08. Dari hasil tersebut terlihat pembelajaran membaca teks drama dengan teknik guided note taking dapat membantu peserta didik dalam membaca teks drama.

Siklus II peserta didik mengalami peningkatan dibanding siklus I. Siklus II ini skor rata-rata peserta didik memperoleh peningkatan menjadi 
81,50, dari siklus I dan II. Berikut ini adalah hasil mengidentifikasi unsur intrinsik dan menuliskan kembali teks drama peserta didik dari nilai kategori nilai rendah, nilai sedang, dan nilai tinggi dari siklus I sampai siklus II. Berdasarkan hasil tes akhir siklus II skor rata-rata peserta didik mengalami peningkatan melalui teknik guided note taking dengan rincian pada Tabel 1. berikut.

Tabel 1. Nilai Kemampuan Membaca Teks Drama yang Dicapai Peserta Didik Kelas VIIIB SMP Negeri 2 Mamasapada Tes Akhir Siklus I dan Tes Akhir Siklus II

\begin{tabular}{|c|c|c|c|c|c|c|}
\hline \multirow{2}{*}{ No. } & \multirow{2}{*}{ Interval } & \multirow{2}{*}{ Nilai } & Kategori & \multicolumn{2}{|c|}{ Frekuensi } & \multicolumn{2}{c|}{ Persentase \% } \\
\cline { 4 - 7 } & & & Siklus & Siklus & Siklus & Siklus \\
& & I & II & I & II \\
\hline 1 & $90-100$ & Sangat Tinggi & 0 & 0 & 0,00 & 0,00 \\
\hline 2 & $75-89$ & Tinggi & 13 & 23 & 50,00 & 88,46 \\
\hline 3 & $60-74$ & Sedang & 12 & 3 & 46,15 & 11,54 \\
\hline 4 & $45-59$ & Rendah & 1 & 0 & 3,85 & 0,00 \\
\hline 5 & $0-44$ & Sangat Rendah & 0 & 0 & 0,00 & 0,00 \\
\hline \multicolumn{3}{|c|}{ Jumlah } & $\mathbf{2 3}$ & $\mathbf{2 3}$ & $\mathbf{1 0 0 , 0 0}$ & $\mathbf{1 0 0 , 0 0}$ \\
\hline
\end{tabular}

Berdasarkan data pada tabel 10 tersebut dapat dijelaskan bahwa pada tes akhir siklus I terdapat 13 orang atau sebesar $50 \%$ peserta didik yang berada pada kategori tinggi, sedangkan pada siklus II mengalami peningkatan menjadi 23 orang peserta didik atau sebesar 88,46\%. Selanjutnya pada tes akhir siklus I terdapat 12 orang atau $46,15 \%$ peserta didik yang berada pada kategori sedang dan pada siklus II menurun 
menjadi 3 orang atau 11,54\%. Untuk kategori rendah terdapat 1 orang atau 3,85 pada siklus I dan berubah pada siklus II menjadi $0,00 \%$.

Hal ini menunjukkan adanya peningkatan kemampuan membaca teks drama yang dicapai peserta didik kelas VIIIB SMP Negeri 2 Mamasa pada siklus II dibandingkan pada siklus I. Ditinjau dari segi rata-rata, nilai rata-rata kamampuan membaca teks drama yang dicapai peserta didik kelas VIIIB SMP Negeri 2 Mamasa pada tes akhir siklus I adalah sebesar 73,385 dan nilai rata-rata kamampuan membaca teks drama yang dicapai peserta didik pada tes akhir siklus II mengalami peningkatan menjadi 78,192. Hal ini menunjukan bahwa kamampuan membaca teks drama yang dicapai peserta didik kelas VIIIB SMP Negeri 2 Mamasa mengalami peningkatan setelah pelaksanaan tindakan pembelajaran membaca teks drama melalui teknik guided note taking pada siklus II.

Selanjutnya untuk mengetahui ketuntasan belajar membaca teks drama yang dicapai peserta didik kelas VIIIB SMP 2 Mamasa melalui tes akhir siklus I dan melalui tes akhir siklus II dapat dilihat pada tabel 2. berikut.

Tabel 2. Deskripsi Ketuntasan Belajar Membaca Teks Drama yang Dicapai Peserta Didik Kelas VIIIB SMP Negeri 2 Mamasa pada Tes Akhir Siklus I dan Tes Akhir Siklus II

\begin{tabular}{|c|c|c|c|c|c|c|}
\hline \multirow{2}{*}{ No. } & \multirow{2}{*}{$\begin{array}{c}\text { Interval } \\
\text { Nilai }\end{array}$} & \multirow{2}{*}{ Kategori } & \multicolumn{2}{|c|}{ Frekuensi } & \multicolumn{2}{c|}{ Persentase \% } \\
\cline { 4 - 7 } & & $\begin{array}{c}\text { Siklus } \\
\text { I }\end{array}$ & $\begin{array}{c}\text { Siklus } \\
\text { II }\end{array}$ & $\begin{array}{c}\text { Siklus } \\
\text { I }\end{array}$ & $\begin{array}{c}\text { Siklus } \\
\text { II }\end{array}$ \\
\hline 1 & $0-74$ & $\begin{array}{c}\text { Tidak } \\
\text { Tuntas }\end{array}$ & 17 & 3 & 65,38 & 11,54 \\
\hline 2 & $75-100$ & Tuntas & 9 & 23 & 34,62 & 88,46 \\
\hline \multicolumn{3}{|c|}{ Jumlah } & $\mathbf{2 6}$ & $\mathbf{2 6}$ & $\mathbf{1 0 0}$ & $\mathbf{1 0 0}$ \\
\hline
\end{tabular}


Berdasarkan tabel 2 dapat dijelaskan bahwa jumlah peserta didik yang masuk kategori tuntas berdasarkan hasil tes akhir siklus I adalah sebanyak 9 orang atau sebesar $34,62 \%$ dan mengalami peningkatan menjadi 23 orang atau meningkat menjadi 88,46\% pada tes akhir siklus II. Sedangkan peserta didik yang masuk kategori tidak tuntas berdasarkan hasil tes akhir siklus I adalah sebanyak 17 orang atau sebesar $65,38 \%$ mengalami penurunan menjadi 3 orang atau menurun menjadi $11,54 \%$ pada tes akhir siklus II. Hal ini dapat ditafsirkan bahwa kamampuan menulis kreatif naskah drama yang dicapai peserta didik kelas VIIIB SMP Negeri 2 Mamasa mengalami peningkatan setelah melalui pembelajaran membaca teks drama teknik guided note taking selama dua siklus.

Penelitian tindakan kelas untuk meningkatkan keterampilan membaca teks drama peserta didik kelas VIIIB SMP Negeri 2 Mamasa melalui teknik guided note taking ini diakhiri pada siklus II. Hal ini didasarkan pada hasil diskusi peneliti dengan guru kolaborator yang melihat sudah adanya peningkatan produk serta proses pembelajaran. Peningkatan yang terjadi sudah memenuhi kriteria keberhasilan tindakan. Selain itu, penelitian dihentikan karena keterbatasan jadwal penelitian serta banyaknya materi pembelajaran yang belum disampaikan oleh guru kepada peserta didik.

Pada penelitian ini terdapat kendala lain yang terjadi. Salah satu kendala yang terjadi selama penelitian dari pelaksanaan pratindakan sampai akhir siklus I, ada peserta didik yang tidak mengikuti pembelajaran. Pada pratindakan ada peserta didik yang tidak masuk 
karena sakit, ada pula yang izin. Begitupun yang terjadi pada siklus I. Hal tersebut menjadikan peneliti sulit dalam menilai peserta didik namun, tugas peserta didik tetap masuk atau tetap ada yang disetor kepada guru karena peneliti memberikan tugas kembali bagi peserta didik yang tidak hadir pada pelajaran sebelumnya sebagaimana tugas yang telah diberikan kepada peserta didik pada pembelajaran sebelumnya.

\section{SIMPULAN}

Berdasarkan hasil penelitian dan pembahasan yang ditemukan pada bab sebelumnya, maka dapat disimpulkan bahwa teknik guided taking dapat meningkatkan pembelajaran keterampilan membaca teks drama peserta didik kelas VIIIB SMP Negeri 2 Mamasa Kabupaten Mamasa. Peningkatan yang terjadi dalam pembelajaran membaca teks drama ini terlihat dari proses pembelajaran, produk yang dihasilkan dari pembelajaran, serta dari keberhasilan Peserta didik dalam mencapai standar ketuntasan pembelajaran.

\section{SARAN DAN REKOMENDASI}

Berdasarkan hasil penelitian melalui teknik guided note takinguntuk meningkatkan keterampilan membaca teks drama, maka direkomendasikan dalam penelitian ini adalah sebagai berikut.

1. Teknik guided note takingdapat dijadikan sebagai salah satu alternatif teknik pembelajaran dalam keterampilan membaca teks drama.

2. Guru dapat menambah referensi teknik pembelajaran membaca, khususnya membaca teks drama. 
3. Teknik guided note taking dapat meningkatkan motivasi peserta didik dalam pembelajaran membaca teks drama.

\section{DAFTAR PUSTAKA}

Arikunto,Suharsimi.2008. penelitianTindakan Kelas. Jakarta:

\section{BumiAksara}

Depdiknas, 2009. Penilaian Jakarta: Departemen Pendidikan Nasional .

Masdudi \& Nasehudin, 2009. Pengantar Ilmu Pendidikan. Cirebon: AlTarbiyah Press.

Nana Syaodiah. 2010. Metode Penelitian Pendidikan. Bandung: Rosdakarya

Sudjana dan Rivai. 2002. Media Pengajaran. Bandung: CV. Sinar Baru.

Suprijono, Agus. 2011. Cooperative Learning Teori dan Aplikasi PAIKEM. Yogyakarta: Pustaka Belajar.

Sutrisno Hadi. 2000. Metodologi Research 2. Yogyakarta: Andi

Zaini. 2002. Strategi Pembelajaran Aktif. Yogyakarta: CDS. 